\title{
Prim@ Facie
}

\section{Diálogos democráticos à luz dos direitos humanos}

A Prim@Facie: Revista do Programa de Pós-Graduação em Ciências Jurídicas da UFPB, no seu número 38, vem à lume trazendo como tema central que une os trabalhos aqui reunidos a ideia democrática. Assim, intitulada “Diálogos democráticos à luz dos direitos humanos", a proposta inicial desta edição é reverberar as construções sociais e políticas que trazem a preocupação com o exercício democrático e das liberdades humanas.

O Programa de Pós-Graduação em Ciências Jurídicas considera essencial que as discussões que tem como foco os direitos humanos e o desenvolvimento sejam travas na esfera das preocupações democráticas, o que se alinha à preocupação com o debate público sobre os problemas enfrentados hodiernamente na sociedade brasileira.

Assim, esta edição une-se ao primeiro número do ano de 2019 "Constitucionalismo e perspectivas pluridimensionais dos Direitos Humanos" de modo a, de forma alvissareira, contribuir com as reflexões acerca dos diálogos democráticos que viabilizam a resistência diante dos avanços autoritários que ameaçam a produção do conhecimento científico no Brasil e no mundo. 
O obscurantismo apenas pode ser afastado quando, dentro da produção científica, sejam colocadas em evidência, as discussões que reflitam acerca da realidade e proponham novas possibilidades de resistência e enfrentamento diante das dificuldades sociais. $\mathrm{Na}$ mesma medida, o contexto econômico e político deve ser considerado como parte da praxis democrática. Desta feita, abertos às contribuições de autores do Brasil e do mundo, os editores encilharam o presente dossiê, o qual tenta estabelecer as conexões entre os debates acadêmicos e a realidade social, colocando a Ciência Jurídica como arena para construção de novas possibilidades para o futuro da democracia.

O primeiro trabalho a compor a seção Corpus, representa bem a preocupação com o mais amplo acesso à atividade e à produção jurídica, refletindo sobre as formas para se democratizar e permitir o contato direito entre os cidadãos e o mundo do direito. Os autores, Maiquel Ângelo Dezordi Wermuth e José Ricardo Maciel Nerling, no trabalho "A DEMOCRATIZAÇÃO DA JUSTIÇA BRASILEIRA ENTRE SÍMBOLOS, RITUAIS E "JURIDIQUÊS": NOTAS POR UMA JUSTIÇA CIDADÃ", tratam da dificuldade existente na democratização do acesso à Justiça, demonstrando de que forma a simbologia que envolve todas as formas de linguagem pode se tornar verdadeiro obstáculo ao acesso amplo pelos cidadãos ao sistema jurídico e à própria Justiça

No trabalho "A INICIATIVA POPULAR LEGISLATIVA COMO INSTRUMENTO DE CONTRAPOSIÇÃO ENTRE ATIVISMO JUDICIAL E POPULAR" de Caroline Ferri, Daniel Lena Marchiori Neto e Bruna Bottero Corrêa, se observa, a partir da articulação com a teoria dialógica oriunda da vertente do Constitucionalismo Popular, proposto pelo constitucionalista norte-americano Mark Tushnet, como o ativismo popular, de forma eventualmente contraposta ao ativismo judicial, pode promover os diálogos institucionais capazes de estabelecer e viabilizar a praxis democrática e realizar uma nova formulação de cidadania participativa. 
Ronny Max Machado, Marco Antonio Barbosa e Magali Rodrigues de Souza, discutem as noções de sociedade em rede, coletivismo, individualismo e os reflexos no direito, a partir das ideias de Fritjof Capra e Castells, para quem, através de diferentes abordagens, convergem para o mesmo pensamento de que o mundo seria uma grande rede onde todos estão interligados, em conexões locais, dentro de outras globais, sendo o principal desafio saber qual o papel do direito nesse contexto. No texto "DIREITO NA SOCIEDADE DA INFORMAÇÃO: PARADOXOS DA SOCIEDADE EM REDE - COLETIVIDADE $\mathrm{X}$ INDIVIDUALISMO NAS COMUNIDADES REAIS E VIRTUAIS", essa visão múltipla e complexa da ciência jurídica, acaba por reconhecer que, no contexto da realidade e não da idealidade dos referidos autores, o papel do direito permanece de difícil precisão ou objetivação, tanto em razão da dificuldade ou impossibilidade de conceituá-lo univocamente, quanto porque ele não apenas se expressa como também é apreendido e utilizado de formas diversas, encontrando-se em permanente processo de adequação e modificação, o que exige democraticamente a participação dos sujeitos sociais.

O trabalho seguinte, "PATRIMÔNIO HISTÓRICO-CULTURAL COMO DIREITO FUNDAMENTAL DE PRESERVAÇÃO DA MEMÓRIA COLETIVA", de Fabricio Veiga Costa e Stella de Oliveira Saraiva debruça-se sobre como o patrimônio histórico-cultural deve ser vislumbrado como direito fundamental à preservação da memória coletiva. Os autores reconhecem que o Estado Democrático de Direito, detém esses valores como base e sustentáculo da sociedade brasileira e que, portanto, deve atuar no sentido de preservar e promover a memória coletiva.

No trabalho que encerra a seção Corpus deste número, intitulado "DIREITO HUMANO AO DESENVOLVIMENTO DOS POVOS INDÍGENAS", Walkiria Martinez Heinrich Ferrer e Everton Neves dos Santos discutem o tema do direito humano ao desenvolvimento dos povos indígenas, destacando que, apesar de 
algumas conquistas no âmbito legal, na prática, os direitos humanos ao desenvolvimento dos povos indígenas ainda não foram devidamente garantidos, devendo ser parte do compromisso democrático brasileiro para efetivação das promessas constitucionais firmadas no Texto de 1988.

Esta edição da Prim@ Facie traz ainda uma seção Artigos, a qual se inicia com o trabalho "VAT-FRAUD PREVENTION TOOLS. CHALLENGES AND POLICY ISSUES IN ITALY" do prof. Italiano Vicenzo Carbone, como parte de uma reflexão acerca de como seria possível reverter as fraudes tributarias que acarretam perdas bilionárias na arrecadação dos Estados-Membros da União Europeia.. Convidado pelos editores, o autor analisa a legislação italiana em matéria de fraude ao IVA, destacando as questões críticas à luz da Diretiva (UE) 2017/1371 do Parlamento Europeu e do Conselho, de 5 de julho de 2017, relativa à luta contra a fraude nos interesses financeiros da União através do direito penal.

Encerrando a edição, apresentamos o trabalho "LIBERALISMO, FEDERALISMO E ENCILHAMENTO NA PRIMEIRA REPÚBLICA BRASILEIRA: A (PERSISTENTE) INFLUÊNCIA DE RUI BARBOSA", no qual Maria Lírida Calou de Araújo e Mendonça e Natallie Alves de Almeida, analisam como Rui Barbosa vislumbrou a organização do Estado com base na forma federativa, e, ainda, qual a atenção dispensada à questão financeira nacional. O trabalho foi desenvolvido dentro das atividades do Grupo de Pesquisa ADMINISTRAÇÃO PÚBLICA E TRIBUTAÇÃO NO BRASIL, vinculado ao Diretório dos Grupos de Pesquisas do CNPq. Vale ressaltar que o trabalho foi construído, nas palavras das autoras, “em razão do centenário de Rui Barbosa, em 2019, razão pela qual o trabalho almeja demonstrar a eventual persistência das contribuições do professor na construção do federalismo brasileiro, ainda que muitos anos após seu falecimento".

Concluído assim o presente editorial, a partir do qual se abre em sequência os trabalhos do presente número, desejo que se cumpra 
o seu objetivo primordial de promover inúmeros outros questionamentos, capazes de promover e ampliar as reflexões acerca do fortalecimento dos processos democráticos à luz da realização dos direitos humanos.

Desejo ainda, a todas e todos uma excelente leitura!

JAILTON MACENA DE ARAÚJO

Editor-Chefe Prim@ Facie, vol. 18, n.38, 2019 